\title{
UROCZYSTOŚCI JUBILEUSZOWE - 95 LAT STOWARZYSZENIA BIBLIOTEKARZY POLSKICH
}

\author{
18.09.2012 r. - Centralna Biblioteka Wojskowa \\ 4.10.2012 r. - Biblioteka Uniwersytecka w Warszawie
}

\subsubsection{2 r. - Centralna Biblioteka Wojskowa}

Z okazji jubileuszu 95-lecia Stowarzyszenia Bibliotekarzy Polskich odbyło się uroczyste spotkanie bibliotekarzy zorganizowane przez Zarząd Okręgu Mazowieckiego SBP i Centralną Bibliotekę Wojskowa. Spotkanie miało miejsce w zawsze gościnnej dla SBP Centralnej Bibliotece Wojskowej im. Marszałka Józefa Piłsudskiego.

W imieniu gospodarzy gości powitała dr hab. Aleksandra Skrabacz, dyrektor CBW, podkreślając różnorodność form działalności Stowarzyszenia, udział młodych bibliotekarzy w tej działalności. Zarówno młodszych jak i starszych członków Stowarzyszenia łączy poczucie przynależności do organizacji jak do rodziny i ogromna satysfakcja z uprawianego zawodu.

W imieniu SBP gości powitała Janina Pasztaleniec-Jarzyńska, przewodnicząca Zarządu Okręgu Mazowieckiego SBP, która odczytała list Elżbiety Stefańczyk, przewodniczącej SBP z gratulacjami za dotychczasową działalność okręgu Mazowieckiego.

Janina Pasztaleniec-Jarzyńska wspomniała również o osobach związanych z bibliotekarstwem, których od tego roku nie ma już wśród nas: Marcin Drzewiecki, Krzysztof Kwiatkowski, Aleksandra Niemczykowa, Bożena Wojnowska, Romana Steczowicz, Jolanta Topolska-Głowacka, Helena Zarachowicz. Ich pamięć uczczono minutą ciszy.

Przewodnicząca Zarządu Okręgu Mazowieckiego przedstawiła misję SBP, która jest działanie na rzecz rozwoju bibliotekarstwa, budowanie tożsamości zawodu bibliotekarza, integracja środowiska, a także kreowanie pozytywnego wizerunku bibliotek i zawodu bibliotekarza.

SBP, jako organizacja pozarządowa o blisko stuletniej tradycji, zrzesza ponad 7,5 tys. osób związanych z bibliotekarstwem i informacją naukowa, z różnych typów bibliotek: publicznych, akademickich, naukowych, specjalnych, szkolnych i pedagogicznych.

Wspominając nazwiska osób zasłużonych dla rozwoju bibliotekarstwa polskiego (m.in. A. Łysakowskiego, J. Muszkowskiego), Joanna Pasztaleniec-Jarzyńska wymieniła również osoby, które działają teraz i tworzą przyszłość polskiego bibliotekarstwa w oddziałach Okręgu Mazowieckiego (Danuta Tomczyk, Jan Marciniak, Henryk Bogusławski).

Po raz pierwszy tak szczegółowo i wyczerpująco zostały zaprezentowane przez Janinę Jagielską, członka Zespołu Historyczno-Pamiętnikarskiego, dzieje 
Okręgu Mazowieckiego SBP, którego struktura ukształtowała się w okresie międzywojennym. 21.10.1917 r. bibliotekarze warszawscy stworzyli własne koło, któremu przewodniczył Faustyn Czerwijowski (pierwszy dyrektor Biblioteki Publicznej m. st. Warszawy).

Historię Oddziału Warszawskiego Janina Jagielska przedstawiła w pięciu blokach chronologicznych: od powstania do 1945 r., w latach 1945-1953, 19541975, 1976-2000, 2001-2012.

Już przed 1945 r. utworzono sekcje: bibliotek naukowych, publicznych, systemu dziesiętnego, badania czytelnictwa, a także poradnię biblioteczna. Powstała również Sekcja pomocy bibliotecznej dla bezrobotnych. Koło prowadziło szeroką działalność edukacyjno-szkoleniową, organizowało kursy bibliotekarskie, wycieczki edukacyjne do bibliotek, spotkania okolicznościowe, zajmowało się wydawaniem publikacji. Również w okresie okupacji odbywały się zebrania Koła w latach 1940-1941.

8.04.1945 r. Koło wznowiło swoją działalność, odbudowało struktury i liczyło około 185 osób. Kontynuowano działalność Koła, utworzono nowe sekcje.

W latach 1954-1975 Koło rozszerzyło swoją działalność, powstawały oddziały miejskie, tworzono sekcje i zespoły problemowe. Aby dokumentować przeszłość i teraźniejszość, utworzono Zespół pamiętnikarski. Pierwsze książki o nieżyjących bibliotekarzach polskich ukazały się w serii Książka o książce, m.in. w 1974 r. „Twórcy nowoczesnego bibliotekarstwa polskiego”.

Lata 1976-2000. Pomimo wprowadzenia stanu wojennego, w 1981 r. działalność oddziału warszawskiego rozwijała się, utworzono 17 kół, do których należały w 2000 r. 672 osoby. Kontynuowano dotychczasowe prace, utworzono Zespół Poradnictwa Zawodowego. Wprowadzono nowe formy działalności, konwersatoria i seminaria bibliotekoznawcze (prowadzone m.in. przez Marię Dembowska), spotkania z ludźmi kultury i nauki, w ramach działalności szkoleniowej zorganizowano kurs podstaw informatyki. Zainicjowano serie „Portrety bibliotekarzy polskich” i „Bibliotekarze polscy we wspomnieniach współczesnych”.

W latach 2001-2012, po reformie administracyjnej w 1998 r. dokonano zmian w strukturze organizacyjnej, tworząc 16 okręgów. Podstawowy zrąb działalności został zachowany.

Nie sposób w takim krótkim sprawozdaniu przenieść całość informacji i nie jest to jego zadaniem. Przedstawiony przez Janinę Jagielską materiał z pewnością zasługuje na upowszechnienie w postaci wydawnictwa. Na koniec wystapienia Janina Jagielska podziękowała osobom, które pomogły w gromadzeniu materiałów, dokumentów, zdjęć potrzebnych do prezentacji.

Przedstawiony przez Janinę Jagielską materiał doskonale uzupełniały wspomnienia dr. Stanisława Czajki, długoletniego prezesa Stowarzyszenia Bibliotekarzy Polskich, z którym od 40 lat jest związany. Obecny honorowy przewodniczący SBP wspomniał o Zjeździe Bibliotekarzy Polskich w Sobieszowie w roku 1989, skromnych finansach Stowarzyszenia, organizacji działalności wydawniczej.

Gościem spotkania był dr Henryk Hollender, dyrektor Biblioteki Uczelni Łazarskiego, który przedstawił prezentację pt. „Od zawodu trudnego do łatwego i z powrotem. O potrzebie kształcenia i zatrudniania bibliotekarzy”. Tematyka prezentacji dotyczyła roli i znaczenia bibliotekarza na przestrzeni wieków w or- 
ganizowaniu działalności bibliotecznej i związanej z tym potrzebie kształcenia, a także zatrudniania bibliotekarzy. Henryk Hollender przedstawił sylwetki zawodowe bibliotekarzy charakterystyczne dla danego okresu w rozwoju piśmiennictwa i bibliotek. Określił zawód bibliotekarza jako łatwy - w kontekście innych zawodów wymagających długoletnich studiów i praktyki, a jednocześnie jako trudny - wobec dzisiejszych wymagań kreujących bibliotekarza jako menadżera humanistę. Jaka więc przyszłość czeka bibliotekarzy XXI w., kiedy pojmowanie zawodu bibliotekarskiego ewoluuje, bardziej liczą się kwalifikacje, a część zadań bibliotekarzy może przejąć wyspecjalizowana firma outsourcingowa. Zdaniem autora prezentacji istnieje możliwość odnowy zawodu bibliotekarskiego poprzez zmianę posiadanych kwalifikacji na takie, które odpowiadają aktualnym potrzebom rynku, czyli bibliotekom i ich użytkownikom.

Dyskusja o użytecznych modelach kształcenia bibliotekarzy toczy się od wielu lat, a przed współczesnym bibliotekarzem stawia się wiele zadań: „[...] musi dobrze czuć się w różnorodnych rolach, powinien być ekspertem w swojej dziedzinie, menedżerem, negocjatorem, badaczem, operatorem baz danych, planistą, znawcą technologii informacyjnych i zasad przedsiębiorczości, a także nauczycielem ciagle otwartym na wiedzę i nowe umiejętności ucznia i użytkownika."1

Pozostałą część spotkania wypełniło rozdanie nagród dla Mazowieckiego Bibliotekarza Roku 2011, Medali „W dowód uznania” oraz Honorowej Odznaki SBP.

\section{Nagroda Mazowieckiego Bibliotekarza Roku 2011}

I miejsce - Anna Skubisz-Szymanowska, dyrektor Miejskiej Biblioteki Publicznej w Radomiu,

II miejsce - Danuta Bucholc, dyrektor Gminnej Biblioteki Publicznej w Lesznowoli,

III miejsce - Zofia Maj, dyrektor Gminnej Biblioteki Publicznej w Zakrzewie.

\section{Medal „W dowód uznania”}

Jolanta Bronikowska-Niemiec (Biblioteka Narodowa),

Bożena Chlebicka-Abramowicz (Centralna Biblioteka Wojskowa),

Maciej Koperski (Biblioteka Narodowa),

Ewa Krawczak (Biblioteka Narodowa),

Hanna Łaskarzewska (Polskie Towarzystwo Bibliologiczne),

Włodzimierz Pigła (Biblioteka Narodowa),

Katarzyna Urbanowicz (Przystanek „Książka” Biblioteka dla Dzieci i Młodzieży nr 41 w Warszawie),

Beata Zych (Pedagogiczna Biblioteka Wojewódzka im. Komisji Edukacji Narodowej w Warszawie)

oraz dwie instytucje:

Wypożyczalnia dla Dorosłych i Młodzieży nr 75 w Warszawie oraz działająca przy tej wypożyczalni Warszawska Galeria Ekslibrisu.

${ }^{1}$ M. Majewska: Kompetencje bibliotekarza wobec zmian edukacyjnych. W: Biblioteka w społeczeństwie informacyjnym. Warszawa 2005, s. 75-80. 


\section{Honorowa odznaka SBP}

Zofia Furman (Powiatowa Biblioteka Publiczna im. Zygmunta Krasińskiego w Ciechanowie),

Katarzyna Janczewska-Sołonko (Biblioteka Narodowa),

Sabina Malinowska (Miejska Biblioteka Publiczna w Ostrołęce),

Joanna Popłońska (Biblioteka Publiczna m.st. Warszawy, Biblioteka Główna Województwa Mazowieckiego),

Bogumiła Tobota (Książnica Płocka).

Spotkanie zakończył koncert pieśni Reprezentacyjnego Zespołu Artystycznego Wojska Polskiego.

\subsubsection{2 r. - Biblioteka Uniwersytecka w Warszawie}

W Bibliotece Uniwersyteckiej w Warszawie odbyły się uroczystości jubileuszowe z okazji 95-lecia istnienia Stowarzyszenia Bibliotekarzy Polskich, 85-lecia „Przeglądu Bibliotecznego” i 50-lecia „Zagadnień Informacji Naukowej". Uroczystości związane z Jubileuszem objął patronatem Minister Kultury i Dziedzictwa Narodowego Bogdan Zdrojewski.

W imieniu gospodarza uroczystości gości, wśród których byli przedstawiciele instytucji i organizacji świata kultury, m.in. Instytutu Książki, Biblioteki Narodowej, Fundacji Rozwoju Społeczeństwa Informacyjnego, Polsko-Amerykańskiej Fundacji Wolności, Stowarzyszenia Księgarzy Polskich, powitała dyrektor Biblioteki Uniwersyteckiej w Warszawie Ewa Kobierska-Maciuszko, pełniąca funkcje wiceprzewodniczącej SBP. Uroczystości Jubileuszowe poprowadził Piotr Maculewicz z Biblioteki Uniwersyteckiej w Warszawie.

Ministra Kultury i Dziedzictwa Narodowego reprezentowała dyrektor Departamentu Mecenatu Państwa w Ministerstwie Kultury i Dziedzictwa Narodowego Zina Jarmoszuk, która w swoim wystapieniu podkreśliła rolę i znaczenie Stowarzyszenia oraz przeczytała list z gratulacjami dla SBP od Ministra Bogdana Zdrojewskiego. Wspomniała również z ogromnym wzruszeniem o swej współpracy z czasopismem „Zagadnienia Informacji Naukowej”, którego przez wiele lat była sekretarzem.

Przewodnicząca Stowarzyszenia Bibliotekarzy Polskich Elżbieta Stefańczyk przedstawiła obszerna prezentacje „To jest SBP”. Przedstawiła również misję Stowarzyszenia, jego historię i najważniejsze postacie z nim związane. Omówiła strukturę SBP i scharakteryzowała różne formy jego działalności: wydawnicza, legislacyjna, edukacyjna, współpracę krajową i międzynarodową, akcje pomocy bibliotekom, promocję bibliotek i czytelnictwa, opiniodawcza, interwencyjna. Oprócz aktualnej działalności wymieniła również projekty na przyszłość, m.in. obchody 100-lecia działalności SBP w roku 2017.

Kolejne wystapienie, redaktor naczelnej Barbary Sosińskiej-Kalaty, poświęcone było najstarszemu polskiemu czasopismu bibliotekarskiemu „Przeglądowi Bibliotecznemu", które obchodzi 85-lecie istnienia. Redaktor naczelna czasopisma przedstawiła historię czasopisma (ukazującego się od 1927 r.), redaktorów, autorów, recenzentów czasopisma, pokazała niewiele zmieniająca się przez 
lata szatę graficzną czasopisma, do której bardzo przywiazani są czytelnicy, traktujący jąjak znak rozpoznawczy czasopisma. „Przegląd Biblioteczny” za lata 1927-2008 dostępny jest także w wersji elektronicznej w Archiwum Cyfrowym SBP. Jego zawartość jest cytowana, m.in. w „Library and Information Science Abstracts”, „Polskiej Bibliografii Bibliologicznej”, „Index Copernicus”. Tytuł czasopisma został umieszczony na liście czasopism punktowanych Ministra Nauki i Szkolnictwa Wyższego. Wkrótce ukaże się również monografia czasopisma autorstwa Zbigniewa Gruszki.

Czasopismem, które również świętowało swój jubileusz były „Zagadnienia Informacji Naukowej”. Redaktor naczelna ZIN Bożenna Bojar pełni tę funkcję od 20 lat, przyczyniając się tym samym do podwójnego jubileuszu czasopisma - 50 lat istnienia („złotego jubileuszu”) i 20 lat pracy nad merytorycznym kształtem czasopisma jego redaktora naczelnego. Bożenna Bojar przedstawiła historię czasopisma wywodzącego się od Biuletynu Ośrodka Dokumentacji i Informacji Naukowej PAN, a przede wszystkim położyła nacisk na znaczenie, jakie przez te lata miało czasopismo dla środowiska informacyjnego². Współczesna informacja naukowa ukształtowała się w latach 50-tych XX w., można więc przyjąć, że czasopismo ma prawie tyle lat ile dziedzina, której dotyczy i na bieżąco mogło przekazywać informacje dotyczące jej rozwoju. „Zagadnienia Informacji Naukowej" za lata 1972-2008 dostępne są także w wersji elektronicznej w Archiwum Cyfrowym SBP. Zawartość czasopisma jest cytowana m.in. W „Library and Information Science Abstracts”, „Knowledge Organization”. Tytuł czasopisma został umieszczony na liście czasopism punktowanych Ministra Nauki i Szkolnictwa Wyższego. Kolejny numer czasopisma, który ukaże się w tym roku, będzie numerem setnym (w ciagłości numerów). Redaktor naczelna Bożenna Bojar podziękowała wszystkim autorom i czytelnikom czasopisma, dzięki którym wydawnictwo to mogło obchodzić swój „złoty jubileusz”.

Po wystapieniach jubileuszowych głos zabrali zaproszeni goście z życzeniami dla Jubilatów, a wśród nich dyrektor Biblioteki Narodowej Tomasz Makowski, który wyraził poparcie dla celów i działalności SBP, dziekan Wydziału Historycznego UW Barbara Zybert, Bożena Koredczuk dyrektor Instytutu Informacji Naukowej i Bibliotekoznawstwa Uniwersytetu Wrocławskiego, Dariusz Kuźmina dyrektor Instytutu Informacji Naukowej i Studiów Bibliologicznych, Hanna Tadeusiewicz z katedry Bibliotekoznawstwa i Informacji Naukowej Uniwersytetu Łódzkiego, przedstawiciele Polskiej Izby Książki, Fundacji Rozwoju Społeczeństwa Informacyjnego i inni.

Kolejnym punktem programu było wręczenie odznaczeń państwowych, resortowych, stowarzyszeniowych. Nagrody otrzymali:

\section{Srebrny Medal „Zasłużony Kulturze Gloria Artis”}

Prof. Bożenna Bojar, redaktor naczelna „Zagadnień Informacji Naukowej”,

Prof. Barbara Sosińska-Kalata, redaktor naczelna „Przeglądu Bibliotecznego",

Elżbieta Stefańczyk, przewodnicząca SBP.

${ }^{2}$ Tekst wystapienia prof. Bożenny Bojar zamieszczony na str. 3. 


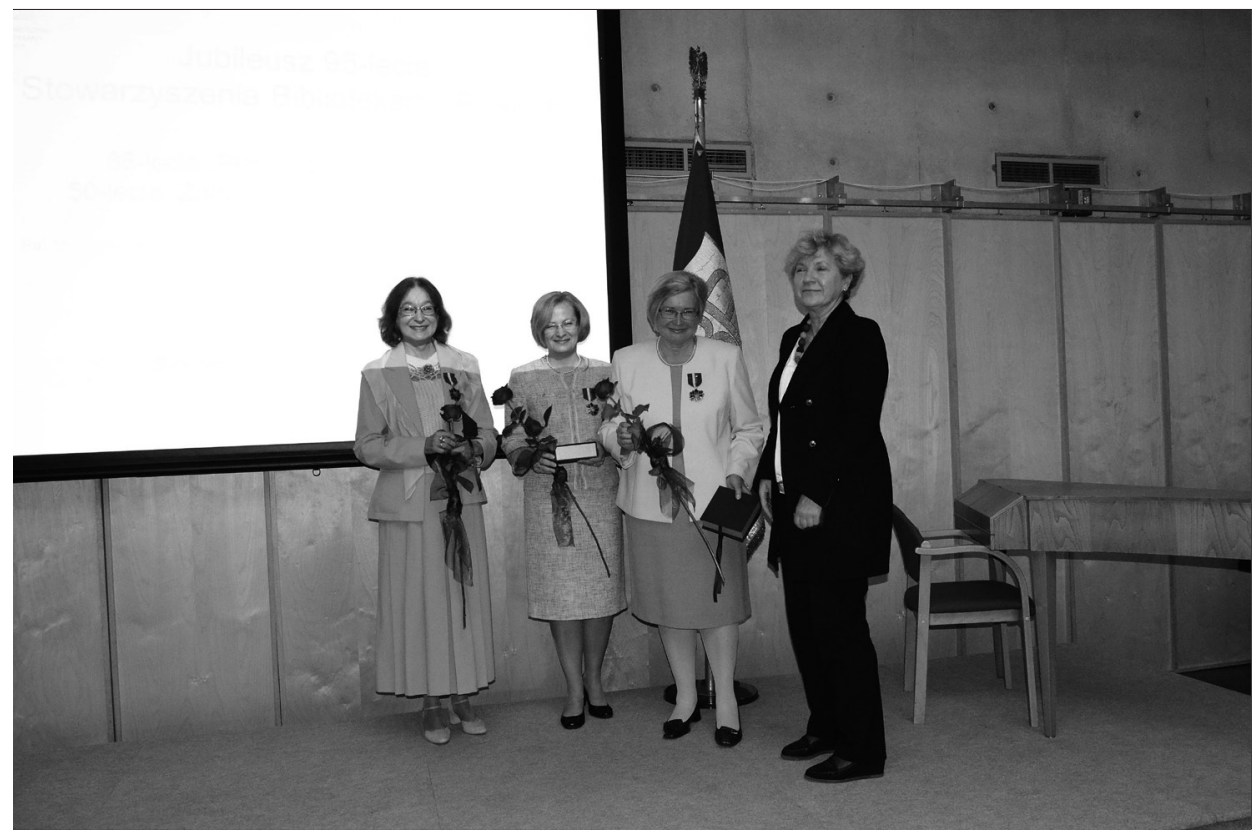

Nagrodzone Srebrnym Medalem „Zasłużony Kulturze Gloria Artis”. Stoją od lewej: redaktor naczelna „Zagadnień Informacji Naukowej” prof. Bożenna Bojar, redaktor naczelna „Przeglądu Bibliotecznego” prof. Barbara Sosińska-Kalata, przewodnicząca SBP Elżbieta Stefańczyk. Medale wręczała dyrektor Departamentu Mecenatu Państwa w Ministerstwie Kultury i Dziedzictwa Narodowego Zina Jarmoszuk

Fot. Jadwiga Antoniak

\section{Brązowy Medal „Zasłużony Kulturze Gloria Artis”}

Elżbieta Kampa - Opole, przewodnicząca ZO SBP, dyrektor MBP w Opolu.

\section{Odznaka Honorowa „Zasłużony dla Kultury Polskiej”}

Bożena Bartoszewicz-Fabiańska - Białystok, Książnica Podlaska, Elżbieta Grzelakowska - Łódź, przewodnicząca ZO SBP w Łodzi, Barbara Kicińska - Chełmża, członek ZO SBP w Toruniu, Elżbieta Nowacka - Toruń, przewodnicząca ZO SBP Toruń.

\section{Złoty Medal „Za Długoletnią Służbę”} SBP),

Sylwia Błaszczyk - Katowice, członek Prezydium ZG, przewodnicząca ZO

Marianna Brachfogel - Warszawa, pracownik Biura ZG SBP,

Stefan Kubów - Wrocław, były przewodniczący SBP, przewodniczący Sekcji Bibliotek Niepaństwowych Szkół Wyższych ZG SBP,

Elżbieta Matusiak - Warszawa, redaktor Wydawnictwa SBP. 


\section{Dyplom Ministra Kultury i Dziedzictwa Narodowego}

Hanna Okońska - Olsztyn, przewodnicząca Oddziału SBP w Olsztynie, Katarzyna Winogrodzka - Warszawa, członek SBP, dyrektor BP Włochy.

\section{Medal „W dowód uznania”}

Agnieszka Gołębiowska - Warszawa, Sekcja Fonotek ZG SBP, Andrzej Spóz - Warszawa, Sekcja Bibliotek Muzycznych ZG SBP.

\section{Honorowa Odznaka Stowarzyszenia Bibliotekarzy Polskich}

Anna Wołodko - Warszawa, BUW.

\section{Nagroda Naukowa SBP im. Adama Łysakowskiego za 2011 r.}

dr hab. Małgorzata Korczyńska-Derkacz z Instytutu Informacji Naukowej i Bibliotekoznawstwa Uniwersytetu Wrocławskiego za prace „Państwowy Instytut Książki (1946-1949) i jego rola w rozwoju bibliologii, bibliotekarstwa i kultury ksiaż̇ki w Polsce".

\section{BIBLIOTEKARZ ROKU 2011}

I miejsce - Małgorzata Kępka, dyrektor Gminnej Biblioteki Publicznej w Koszarawie (woj. śląskie),

II miejsce - Małgorzata Zińczuk, kierownik Działu Udostępniania Zbiorów i Informacji w Miejskiej Bibliotece Publicznej we Włodawie,

III miejsce - Danuta Krajewska, kierownik filii nr 11 Koszalińskiej Biblioteki Publicznej.

Nagroda w konkursie na najlepszy program promocji książek i czytelnictwa - Tydzień Bibliotek

I miejsce - Miejska Biblioteka Publiczna - Galeria Książki w Oświęcimiu (dyrektor Leszek Palus),

II miejsce - Miejska Biblioteka Publiczna w Łańcucie (dyrektor Małgorzata Sońska),

III miejsce - Biblioteka Wydziału Politologii i Studiów Międzynarodowych Uniwersytetu Mikołaja Kopernika w Toruniu (dyrektor Marzenna Cupa).

\section{Medal Bibliotheca magna Perennisque}

Biblioteka Pracy i Zabezpieczenia Społecznego w Warszawie. 
Spotkanie Jubileuszowe zakończył koncert Zespołu Muzyki Dawnej La Tempesta pod kierunkiem Jakuba Burzyńskiego.

Uroczystościom towarzyszyła konferencja zorganizowana przez Komisję ds. Edukacji Informacyjnej (KEI) Zarządu Głównego Stowarzyszenia Bibliotekarzy Polskich oraz Bibliotekę Uniwersytecką w Warszawie „Edukacja informacyjna i medialna. Archipelagi wiedzy".

Anna Stanis

Biblioteka Uniwersytecka w Warszawie 